\title{
Effect of feeding processed sweet sorghum (Sorghum bicolour (L) moench) crushed residue based complete ration on growth performance and feeding behavior of murrah buffalo calves
}

\author{
Ch.Venkata Seshaiah ${ }^{1}$, S. Jagadeeswara Rao ${ }^{1}$, Y. Ramana Reddy ${ }^{2}$, D. Nagalakshmi ${ }^{2}$, M. Mahender ${ }^{3}$ and Ch. Harikrishna $^{3}$ \\ 1. Department of Livestock Production and Management College of Veterinary Science, Sri Venkateswara Veterinary \\ University, Gannavaram. India.; 2. Dept. of Animal Nutrition, CVSc, Rajendranagar, Hydeabad-500030, India; \\ 3. Department of Livestock Production and Management College of Veterinary Science, Sri Venkateswara Veterinary \\ University, Rajendranagar, Hyderabad, India. \\ Corresponding author: Ch.Venkata Seshaiah, email:seshuchappidi@yahoo.com \\ Received: 25-06-2012, Accepted: 23-07-2012, Published online: 27-12-2012
}

How to cite this article: Seshaiah CV, Rao SJ, Reddy YR, Nagalakshmi D, Mahender M and Harikrishna C (2013) Effect of feeding processed sweet sorghum (Sorghum bicolour ( $L$ ) moench) crushed residue based complete ration on growth performance and feeding behavior of murrah buffalo calves, Vet World 6(3): 151-155, doi: 10.5455/vetworld.2013.151-155

\begin{abstract}
Aim: The objective of the present study is to know the effect of feeding processed sweet sorghum (Sorghum bicolour (L) moench) crushed residue (SSCR) based complete ration on growth, feeding behavior and cost of gain in Murrah buffalo calves in order to compare the feeding value of SSCR with sorghum straw (SS) and also find out the efficient way of utilization of SSCR in the diets of growing buffalo calves.

Materials and Methods: Experimental complete rations were formulated with SSCR and concentrate in 50:50 ratio and processed in to SSCR chopped and concentrate (SSCRC), mash (SSCRM) and expander extruder pellets (SSCRP). The control ration was SS based complete feed processed in to mash (SSM). 24 Murrah buffalo calves (Average $137 \mathrm{~kg}$ body weight and aged 1 year 2 months) were randomly distributed into 4 experimental groups of 6 animals each in a completely randomized design and the experimental rations were offered to 4 groups randomly for a period of 150 days. A 7 day digestion trial was conducted at the end of 150 day growth trial to find out the nutrient digestibility of experimental rations. Eating and ruminating activities were noted every 5 minutes, and each activity was assumed to persist for the entire 5 minutes. Sorting behavior in the calves was observed physically at the time of feeding. The cost of the rations was calculated on the basis of processing cost and the prevailing market prices of the feed ingredients.
\end{abstract}

Results: The DM intake (g/d), digestibilities of DM, organic matter, crude protein and nitrogen free extract and nitrogen $(\mathrm{N})$ balance were higher $(\mathrm{P}<0.05)$ in buffalo calves fed SSCRP ration but, comparable among SSCRC, SSCRM and SSM rations. Higher $(\mathrm{P}<0.01)$ average daily gain $(\mathrm{g})$, lower feed conversion ratio $(\mathrm{FCR})$ was observed in calves fed SSCRP ration, while comparable among SSCRC, SSCRM and SSM rations. Eating, rumination and total chewing time (minutes/d, minutes/kg DMI and minutes/kg NDFI) and number of chews for eating, rumination and total chewing (per d, per $\mathrm{kg}$ DMI and per kg NDFI) were higher $(\mathrm{P}<0.01)$ in calves fed SSCRC ration and lower $(\mathrm{P}<0.01)$ in SSCRP ration and comparable among SSCRM and SSM rations. Sorting and selection of ration against large fibrous particles in favour of concentrate portion of the ration was observed in SSCRC ration and was not observed in SSCRP, SSCRM and SSM rations. lower ( $(\mathrm{P}<0.05)$ cost (INR) per kg gain was observed in buffalo calves fed SSCRP ration than those fed SSCRC, SSCRM and SSM rations.

Conclusion: The present study indicated that SSCR may be used as roughage source in place of SS in complete feeds for economic feeding of buffalo calves. Further, expander-extruder processing of the complete ration improved feed intake, growth rate, feed efficiency and decreased sorting behavior and cost of feeding compared to mash and chopped forms of the ration.

Keywords: buffalo calves, complete rations, cost economics, feeding behavior, growth, sweet sorghum crushed residue

\section{Introduction}

Sweet sorghum (Sorghum bicolour (L) moench), a dry land crop is more water use efficient and recently gaining importance as a feedstock for ethanol production [1]. In general, it can produce stalk 54 - 69 t/ha [2]. The crushed residue produced after juice extraction from stalks can be used as animal feed [3]. The feed value of the sweet sorghum crushed residue is not less than the value of non-sweet stem that is currently the main stay of feed market in and around Hyderabad [4]. Feeding of roughages under complete diet system improved the palatability and utilization of bulky crop residues [5]. Various processing methods like grinding [6] and pelleting [7] improved the dry matter intake and digestibility of nutrients. Now a day's expanders are being used in feed industry as an alternative for pelleting for processing of livestock feeds $[8,9]$.

The objective of the present study was to know the effect of feeding processed SSCR based complete ration on growth, nutrient digestibility, feed efficiency, feeding behavior and cost per kg weight gain in Murrah buffalo calves in order to compare the feeding value of SSCR with sorghum straw (SS) and also find out the efficient way of utilization of SSCR in the diets of growing buffalo calves.

\section{Materials and Methods}

The variety of sweet sorghum used in the present 
Table-1. Ingredient and chemical composition of experimental complete rations

\begin{tabular}{|c|c|c|c|c|}
\hline Ingredient/Nutrient & SSM & SSCRC & SSCRM & SSCRP \\
\hline \multicolumn{5}{|c|}{ Ingredient composition (kg/100kg) } \\
\hline Maize & 31.0 & 31.0 & 31.0 & 31.0 \\
\hline Ground nut cake & 16.5 & 16.5 & 16.5 & 16.5 \\
\hline Sunflower cake & 20.0 & 20.0 & 20.0 & 20.0 \\
\hline Deoiled rice bran & 23.0 & 23.0 & 23.0 & 23.0 \\
\hline Molasses & 5.0 & 5.0 & 5.0 & 5.0 \\
\hline Urea & 1.5 & 1.5 & 1.5 & 1.5 \\
\hline Mineral mixture & 2.0 & 2.0 & 2.0 & 2.0 \\
\hline Salt & 1.0 & 1.0 & 1.0 & 1.0 \\
\hline Sweet sorghum crushed residue & - & 50.0 & 50.0 & 50.0 \\
\hline Jowar straw (CSV-5 variety) & 50.0 & - & - & - \\
\hline Vitaminutes $\mathrm{AD}_{3}$ (g/qt) & 20.0 & 20.0 & 20.0 & 20.0 \\
\hline \multicolumn{5}{|c|}{ Chemical composition (\% DM basis) } \\
\hline Dry matter & 92.36 & 92.45 & 92.57 & 92.38 \\
\hline Organic matter & 90.32 & 90.31 & 90.23 & 90.27 \\
\hline Crude protein & 11.15 & 11.55 & 11.66 & 11.73 \\
\hline Ether extract & 1.34 & 2.00 & 1.98 & 1.99 \\
\hline Crude fibre & 27.39 & 26.85 & 27.13 & 26.95 \\
\hline Nitrogen free extract & 50.44 & 49.91 & 49.46 & 49.60 \\
\hline Neutral detergent fibre & 9.68 & 9.69 & 9.77 & 9.73 \\
\hline Acid detergent fibre & 31.11 & 29.48 & 30.22 & 29.67 \\
\hline Hemicellulose & 21.43 & 25.52 & 22.33 & 22.80 \\
\hline Cellulose & 21.46 & 23.27 & 23.66 & 23.35 \\
\hline Lignin & 4.19 & 3.43 & 3.94 & 3.78 \\
\hline
\end{tabular}

*Each value is the average of three observations. On dry matter basis except for dry matter

study was SSV 84 developed by ICRISAT (International Crops research Institute for the Semi Arid Tropics) and propagated by the farmers in Medak District of Andhra Pradesh. The crop was harvested at 135 days after sowing and crushed at the decentralized sweet sorghum crushing unit established by ICRISAT at Ibrahimbad village of Medak District in Andhra Pradesh. The required quantity of SSCR was procured from the crushing unit and sundried for the preparation of experimental rations. Twenty four Murrah buffalo calves with uniform body weight $(137 \mathrm{~kg})$ and age (1year 2 months) were distributed randomly into four experimental groups of six animals each in a completely randomized design. Experimental complete rations were formulated with SSCR and concentrate in 50:50 ratio and processed in to chopped SSCR and concentrate (SSCRC), mash (SSCRM) and expander-extruder pellets (SSCRP). The control diet was formulated using sorghum straw (SS) in the same roughage to concentrate ratio and processed in to mash form (SSM). The complete rations were offered to four groups of buffalo calves randomly for a period of 150 days. The animals were weighed fortnightly for 3 consecutive days before offering feed and water in the morning. A 7 day digestion trial was conducted at the end of 150 day growth trial. The samples were analyzed for proximate principles [10] and fibre fractions [11]. Metabolizable energy (ME) values were calculated from total digestible nutrients (TDN) using factors suggested [12]. Eating and ruminating behavior were monitored visually for a $24 \mathrm{~h}$ period in shifts of 8 hours during the last 3 days of the growth trial. Eating and ruminating activities were noted every 5 minutes, and each activity was assumed to persist for the entire 5 minutes. To estimate the time spent for eating, ruminating and total chewing per $\mathrm{kg}$ dry matter intake (DMI) and neutral detergent fibre intake (NDFI), the actual intake for that day was used.
A period of rumination was defined as at least 5 minutes of rumination occurring after at least 5 minutes without rumination activity. Total chewing time was determined as the sum of total eating and ruminating times. The number of chews per day was calculated by the following formulas [13].

Eating chews (number day) $=-5854+84.75 \times$ eating time (minutes/d).

Ruminating chews (number per day) $=-81+71.29 \times$ ruminating time (minutes/d).

Total chews (number per $d)=-12390+80.59 \times$ total chewing time (minutes/d).

Sorting behavior of the calves observed physically during feeding of the calves for last three days of the growth trial. Statistical analysis of the data was carried out according to the procedures suggested [14]. The costs of the rations were calculated on the basis of processing cost and the prevailing market prices of the feed ingredients.

Ethical approval: The study was approved by Institutional Animal Ethics Committee on $17^{\text {th }}$ October 2010

\section{Results and Discussion}

Chemical composition of SSCR: SSCR on dry matter basis contained $92.5 \%$ dry matter (DM), $90.75 \%$ organic matter $(\mathrm{OM}), 3.94 \%$ crude protein (CP), $1.89 \%$ ether extract (EE), $37.58 \%$ crude fibre (CF), $47.34 \%$ nitrogen free extract (NFE), $9.2 \%$ total ash (TA), 74.76\% neutral detergent fiber (NDF), $42.93 \%$ acid detergent fiber (ADF), $31.84 \%$ cellulose, $37.75 \%$ hemicellulose and $4.24 \%$ lignin. The proximate principles of SSCR were comparable with sorghum and maize stovers [15]. The CP per cent of SSCR was comparable with sorghum stover [16].

The NDF and ADF content of sorghum and maize stovers [15] and stripped leaves of sweet sorghum 
Table-2. Effect of feeding differently processed sweet sorghum crushed residue based complete rations on nutrient digestibility (\%) in murrah buffalo calves

\begin{tabular}{|c|c|c|c|c|c|}
\hline Nutrient & SSM & SSCRC & SSCRM & SSCRP & SE \\
\hline \multicolumn{6}{|l|}{ Intake (unit/kg $\mathbf{w}^{0.75}$ ) } \\
\hline Dry matter $(\mathrm{g})$ & $96.97^{b}$ & $93.46^{b}$ & $93.71^{b}$ & $95.37^{a}$ & 0.83 \\
\hline Water intake (g) & 426.50 & 434.80 & 420.70 & 422.50 & 0.21 \\
\hline \multicolumn{6}{|l|}{ Nutrient digestibility } \\
\hline Dry matter & $64.71^{\mathrm{b}}$ & $64.60^{\mathrm{b}}$ & $64.64^{\mathrm{b}}$ & $66.60^{\mathrm{a}}$ & 0.20 \\
\hline Organic matter & $67.25^{\mathrm{b}}$ & $67.66^{b}$ & $67.35^{\mathrm{b}}$ & $69.67^{\mathrm{a}}$ & 0.31 \\
\hline Crude protein & $65.82^{b}$ & $65.99^{b}$ & $66.05^{\mathrm{b}}$ & $69.91^{\mathrm{a}}$ & 0.47 \\
\hline Ether extract & 66.09 & 67.25 & 66.24 & 67.51 & 0.52 \\
\hline Crude fibre & 60.56 & 60.79 & 59.82 & 59.73 & 0.86 \\
\hline Nitrogen free extract & $66.23^{b}$ & $66.30^{b}$ & $66.43^{b}$ & $68.70^{a}$ & 0.34 \\
\hline Neutral detergent fibre & 53.87 & 53.49 & 53.84 & 53.62 & 0.53 \\
\hline Acid detergent fibre & 51.55 & 51.31 & 51.32 & 50.75 & 0.41 \\
\hline Hemicellulose & 69.67 & 70.87 & 52.49 & 52.65 & 0.51 \\
\hline Cellulose & 52.97 & 53.37 & 52.49 & 52.65 & 0.62 \\
\hline Nitrogen intake $(\mathrm{g})$ & $82.97^{b}$ & $82.82^{b}$ & $86.22^{\mathrm{a}}$ & $88.28^{\mathrm{a}}$ & 0.72 \\
\hline Nitrogen Balance (g/d) & $26.15^{\mathrm{b}}$ & $25.66^{b}$ & $27.45^{b}$ & $33.01^{\mathrm{a}}$ & 0.82 \\
\hline \multicolumn{6}{|l|}{ Nutritive value of the rations } \\
\hline Digestible crude protein (\%) & $7.34^{b}$ & $7.62^{b}$ & $7.70^{b}$ & $8.20^{a}$ & 0.08 \\
\hline Total digestible nutrient (\%) & 59.33 & 60.06 & 59.74 & 61.40 & 0.36 \\
\hline Metabolizable energy (MJ) & 8.98 & 9.09 & 9.04 & 9.29 & 0.05 \\
\hline
\end{tabular}

Each value is the average of three observations, a,b: values bearing different superscripts in a row differ significantly ( $P<0.05$ )

hybrids [4] were comparable with SSCR. However, compared to SSCR, lower values of $\operatorname{NDF}(52.82 \%)$ and ADF (46.51\%) content were reported in sorghum stover [16] might be due to difference in stage of harvesting.

The chemical composition of processed SSCR rations were comparable (Table-1) as the processing does not have any effect on chemical composition among mash and pelleted rations [17].

Dry matter intake: The DMI $(\mathrm{g} / \mathrm{d})$ was higher $(\mathrm{P}<0.05)$ in buffalo calves fed SSCRP ration, while comparable among SSCRC, SSCRM and SSM rations (Table 2). This might be due to more palatability of pelleted ration resulted into more feed intake of expander-extruder complete diets $[5,18]$.

However, no significant difference was found in water intake among buffalo calves fed different experimental rations.

Nutrient digestibilities: The average DM, OM, CP and NFE digestibilities were higher $(P<0.05)$ in calves fed SSCRP ration, but comparable among SSCRC, SSCRM and SSM rations (Table-2). This might be due to heat treatment of the complete ration during expander-extruder processing which might have protected protein from ruminal degradation resulted for higher CP digestibility and might also helps in gelatinization of the starch components of the feed and loosening of the bonds between lignin and soluble carbohydrates (hemicellulose, xylose etc.) which in turn resulted in higher $(P<0.05)$ energy digestibility [8].

However, significant difference was not observed in the digestibilities of $\mathrm{CF}$ and $\mathrm{EE}$ and cell wall constituents among the differently processed SSCR rations and with control ration corroborating the findings $[8,19]$.

Nitrogen balance: The $\mathrm{N}$ intake $(\mathrm{g} / \mathrm{d})$ and $\mathrm{N}$ balance $(\mathrm{g} / \mathrm{d})$ were higher $(\mathrm{P}<0.05)$ in calves fed SSCRP ration compared to those fed SSCRC, SSCRM and SSM rations (Table-2) reflecting $\mathrm{CP}$ digestibility pattern among the experimental rations. Higher $\mathrm{N}$ balance might be due to better CP digestibility of expanderextruder ration over mash and chopped form of the rations [20]. All the buffalo calves showed positive nitrogen balance.

Nutritive value: Higher $(P<0.05)$ DCP $(\%)$ content and intake in buffalo calves fed SSCRP ration (Table 2) might be due to higher $(P<0.05)$ digestibility and intake of $\mathrm{CP}$ due to expander-extruder processing [5]. The trend of TDN (\%) and ME (MJ/kg DM) content and intake of SSCRP ration was similar to that of DCP (\%) content and intake but the difference among the rations were not significant. All the buffalo calves fed differently processed complete rations met the DM, DCP and TDN requirements recommended [21].

Feeding behavior: Eating, rumination and total chewing time (minutes/d, minutes/kg DMI and minutes $/ \mathrm{kg}$ NDFI) and number of chews for eating, rumination and total chewing (per d, per kg DMI and per kg NDFI) were higher $(\mathrm{P}<0.01)$ in buffalo calves fed SSCRC ration compared to those fed SSCRM, SSCRP and SSM rations and lower $(\mathrm{P}<0.01)$ in calves fed SSCRP ration compared to those fed SSCRC, SSCRM and SSM rations. This might be due larger particle size and less dense nature of the SSCRC ration compared to SSCRP, SSCRM and SSM rations. Lower eating and chewing time in buffalo calves fed SSCRP ration might be due to easier consumption of the pellets [19] resulting on higher intakes [18]. The rumination time per unit DM intake decreased with decreasing dietary particle size [22] in cattle corroborates with the present findings of lower rumination in SSCRP followed by SSCRM and SSM rations.

However, the difference in time required and number of chews for eating, rumination and total chewing were not significant in buffalo calves fed SSCRM and SSM 
Table-3. Effect of feeding processed sweet sorghum crushed residue based complete rations on eating and rumination in murrah buffalo calves

\begin{tabular}{|c|c|c|c|c|c|}
\hline \multirow[t]{2}{*}{ Parameter } & \multicolumn{4}{|c|}{ Ration } & \multirow[t]{2}{*}{ Mean \pm SEM } \\
\hline & SSM & SSCRC & SSCRM & SSCRP & \\
\hline \multicolumn{6}{|l|}{ Eating } \\
\hline Minutes/d & $237.00^{\mathrm{b}}$ & $256.80^{\mathrm{a}}$ & $236.30^{\mathrm{b}}$ & $196.00^{c}$ & $231.50 \pm 5.72$ \\
\hline Minutes/kg DMI & $51.97^{b}$ & $57.37^{a}$ & $51.30^{b}$ & $41.67^{c}$ & $50.57 \pm 1.54$ \\
\hline Minutes/Kg NDFI & $96.61^{b}$ & $108.98^{a}$ & $92.01^{b}$ & $79.11^{c}$ & $94.17 \pm 2.90$ \\
\hline No. of chews/d & $9892.55^{b}$ & $12274.03^{a}$ & $9799.33^{b}$ & $7316.15^{\mathrm{c}}$ & $9820.51 \pm 454.02$ \\
\hline Chews/kg DMI & $2168.60^{b}$ & $2743.84^{\mathrm{a}}$ & $2127.86^{b}$ & $1555.82^{c}$ & $2149.03 \pm 111.05$ \\
\hline Chews/kg NDFI & $4031.60^{b}$ & $5212.47^{\mathrm{a}}$ & $3816.11^{b}$ & $2953.34^{c}$ & $4003.38 \pm 212.82$ \\
\hline \multicolumn{6}{|l|}{ Ruminating } \\
\hline Minutes/d & $480.50^{b}$ & $514.00^{a}$ & $481.50^{\mathrm{b}}$ & $401.50^{c}$ & $469.38 \pm 10.77$ \\
\hline Minutes/kg DMI & $105.36^{b}$ & $114.87^{\mathrm{a}}$ & $104.56^{b}$ & $85.39^{\circ}$ & $102.54 \pm 2.96$ \\
\hline Minutes/Kg NDFI & $195.88^{b}$ & $218.23^{a}$ & $187.51^{\mathrm{b}}$ & $162.09^{c}$ & $190.92 \pm 5.56$ \\
\hline No. of chews/d & $22520.50^{b}$ & $26256.10^{a}$ & $22327.90^{\mathrm{b}}$ & $18332.20^{\circ}$ & $22359.18 \pm 724.62$ \\
\hline Chews/kg DMI & $4938.09^{b}$ & $5867.74^{\mathrm{a}}$ & $4847.90^{b}$ & $3897.55^{\mathrm{c}}$ & $4887.82 \pm 186.07$ \\
\hline Chews/kg NDFI & $9180.32^{b}$ & $11146.93^{a}$ & $8694.23^{b}$ & $7398.53^{c}$ & $9105.00 \pm 358.65$ \\
\hline \multicolumn{6}{|l|}{ Total chewing } \\
\hline Minutes/d & $717.50^{b}$ & $770.80^{a}$ & $717.80^{\mathrm{b}}$ & $597.50^{\circ}$ & $700.86 \pm 16.45$ \\
\hline Minutes/kg DMI & $157.33^{b}$ & $172.24^{\mathrm{a}}$ & $155.86^{b}$ & $127.06^{\mathrm{c}}$ & $153.12 \pm 4.49$ \\
\hline Minutes/Kg NDFI & $292.49^{b}$ & $327.21^{a}$ & $279.52^{b}$ & $241.19^{c}$ & $285.10 \pm 8.44$ \\
\hline No. of chews/d & $32413.03^{b}$ & $38600.02^{a}$ & $32127.32^{b}$ & $25648.34^{\mathrm{c}}$ & $32197.17 \pm 1183.29$ \\
\hline Chews/kg DMI & $7106.69^{b}$ & $8625.52^{a}$ & $6975.77^{b}$ & $5453.37^{c}$ & $7040.34 \pm 297.14$ \\
\hline Chews/kg NDFI & $13211.92^{b}$ & $16385.87^{\mathrm{a}}$ & $12510.34^{b}$ & $10351.87^{c}$ & $13115.00 \pm 571.65$ \\
\hline
\end{tabular}

Each value is the average of four observations, $a, b$ : values bearing different superscripts in a row differ significantly $(P<0.01)$

Table-4. Effect of feeding differently processed sweet sorghum crushed residue based complete rations on growth rate, feed efficiency and cost economics in Murrah buffalo calves

\begin{tabular}{|c|c|c|c|c|c|}
\hline Parameter & SSM & SSCRC & SSCRM & SSCRP & SE \\
\hline Initial Weight $(\mathrm{kg})$ & 136.90 & 137.00 & 137.30 & 136.90 & 0.37 \\
\hline Final weight $(\mathrm{kg})$ ** & $209.60^{b}$ & $205.20^{\mathrm{b}}$ & $209.70^{b}$ & $224.70^{a}$ & 2.56 \\
\hline Weight gain $(\mathrm{kg}) * *$ & $72.70^{\mathrm{b}}$ & $68.20^{\mathrm{b}}$ & $72.40^{\mathrm{b}}$ & $87.80^{\mathrm{a}}$ & 2.05 \\
\hline Average daily gain $(\mathrm{g} / \mathrm{d})^{* *}$ & $484.67^{b}$ & $454.66^{b}$ & $482.67^{b}$ & $585.33^{a}$ & 13.67 \\
\hline Feed intake $(\mathrm{kg} / \mathrm{d})$ * & $4.50^{\mathrm{ab}}$ & $4.42^{b}$ & $4.49^{\mathrm{ab}}$ & $4.56^{a}$ & 0.02 \\
\hline Feed conversion Ratio (kg/kg gain) ${ }^{\star *}$ & $9.29^{b}$ & $9.84^{b}$ & $9.36^{b}$ & $7.80^{\mathrm{a}}$ & 0.23 \\
\hline Cost/kg gain (Rs) ** & $74.55^{\mathrm{a}}$ & $63.22^{b}$ & $61.07^{b}$ & $52.44^{c}$ & 4.55 \\
\hline
\end{tabular}

Each value is the average of six observations, $a, b$ : values bearing different superscripts in a row differ significantly $(P<0.01)$

rations (Table-3) because of the similar physical properties of the complete rations.

Sorting and selection of ration against longer particles of SSCR in favour of smaller particles of the concentrate portion of the ration was observed in calves fed SSCRC ration compared to SSCRP, SSCRM and SSM rations. Similar findings were reported in Holstein Friesian heifers [23] and cattle [24]. However, sorting was not observed in SSCRP, SSCRM and SSM rations. Sorting of the complete ration can be prevented by pelleting and grinding of the feed [25].

Growth rate and cost economics: The higher $(P<0.05)$ feed intake and higher $(P<0.01)$ average daily gain $(\mathrm{g})$ in buffalo calves fed SSCRP ration (Table-4) might be due to easier consumption of pelleted ration and efficient digestibility of nutrients [8] compared to chopped form of the ration. Even though the average daily feed intake $(\mathrm{kg} / \mathrm{d})$ among SSCRM, SSCRP and SSM rations were not significantly different, higher $(1.32 \%)$ daily feed intake $(\mathrm{kg} / \mathrm{d})$ in buffalo calves fed SSCRP ration was observed compared to SSCRM and SSM rations.

The FCR and cost per kg gain (INR) was lower $(P<0.01)$ in buffalo calves fed SSCRP ration compared to those fed SSCRC, SSCRM and SSM rations (Table4). This might be due to efficient digestibility of DM,
$\mathrm{OM}, \mathrm{CP}$ and NFE in buffalo calves fed SSCRP ration than those fed SSCRC, SSCRM and SSM rations corroborating the findings [17]. Even though FCR was not significant in buffalo calves fed either SSM or SSCRC and SSCRM rations, the cost/kg gain (INR) was lower $((\mathrm{P}<0.01)$ in buffalo calves fed SSCRM and SSCRC rations than those fed SSM ration due to higher cost of sorghum straw (INR-4) compared to SSCR (INR-1).

\section{Conclusion}

Based on the results of the present study it was concluded that SSCR may be used as roughage source in place of SS in complete feeds for economic growth rate in buffalo calves. Further, expander-extruder processing of the complete ration improved feed intake, growth rate, feed efficiency and decreased sorting behavior and cost of feeding compared to mash and chopped forms of the ration.

\section{Author's contribution}

CVS, SJR, YRR and DN implemented the study design. CVS and MM recorded and analysed the data. CVS, SJR, YRR and DN drafted and revised the manuscript. All author read and approved the final manuscript 


\section{Acknowledgements}

The authors are thankful to NAIP-ICRISAT Project for the financial support and also thankful to senior scientist, Dairy Experimental Station, College of Veterinary Science, Rajendranagar for providing required number of buffalo calves and facilities to carry out this work.

\section{Competing interests}

Authors declare that they have no competing interest.

\section{References}

1. Reddy, B. V. S., Ramesh, S., Reddy, P. S., Ramaiah, B., Salimath, P. M. and Kachapur, R. (2005). Sweet sorghum - a potential alternative raw material for bio- ethanol and bio energy. International Sorghum and Millets News Letter 46: 79-86.

2. Almodares, A., Taheri, R. and Adeli, S. (2008). Stalk yield and carbohydrate composition of sweet sorghum (sorghum bicolour (L.) Moench) cultivars and lines at different growth stages. J. Malesian Appl. Biol 37: 31-36.

3. Jafarinia, M., Almodares, A. and Khorvash, M. (2005). Using sweet sorghum crushed residue in silo In: Proceedings of $2^{\text {nd }}$ Congress of Using Renewable Sources and Agric. Wastes. Khorasgan Azade university, Isfahan, Iran.

4. Blümmel, M., Rao, S. S., Palaniswami, S., Shah, L. and Reddy, B.V.S. (2009). Evaluation of sweet sorghum (Sorghum bicolor (L.) Moench) used for bio-ethanol production in the context of optimizing whole plant utilization. Anim. Nutri. Feed Tech., 9: 1-10.

5. Nagalakshmi, D. and Narasimha Reddy, D. (2010). Effect of feeding expander-extruder processed complete diet containing sugar cane crushed residue on performance of Murrah Buffaloes. Anim. Nutri. Feed Tech., 10:1-8.

6. Reddy, M. R. (1990). Complete diets based on fibrous crop residues for dairy cattle. Indian Dairyman 42: 180-184.

7. Reddy, M. R., Govindaiah, T. and Reddy, G. V. N. (1992). Effect of physical processing on the nutritive value and nutrient utilization of cotton straw in goats. Proceedings of Vth International conference on goats. March 2-8, 1992, New Delhi, pp: 194 (Abstract).

8. Nagalakshmi, D., Narasimha Reddy, D. and Kishan Kumar, M. (2004). Performance of Murrah buffaloes fed expanderpelleted cotton straw based diets. Anim. Nutri. Feed Tech. 10: $1-8$.

9. Prasad, D. A. (2003). Extrusion-expansion applications in the feed industry. In: Short term course on feed technology, January 20 to $10^{\text {th }}$ Febuary, 2003. Acharya N.G Ranga Agricultural University, Hyderabad, India, pp.102-108.

10. AOAC. (1995). Official Methods of Analysis. $16^{\text {th }}$ ed., Association of Official Analytical Chemist, Washington, D

\section{C, USA.}

11. VanSoest, P J., Robertson, J D. and Lewis, B. A. (1991) Methods for dietary fibre, neutral detergent fibre non-starch polysaccharides in relation to animal nutrition. J. Dairy Sci. 74:3583-3597.

12. NRC. (1989). Nutrient Requirements of Dairy Cattle. $6^{\text {th }}$ rev.ed. National Academy Press, Washington, DC.

13. Allen, M. S. (1997). Relationship between fermentation acid production in the rumen and the requirement for physically effective fibre. J. Dairy Sci. 80: 1447-146.

14. Snedecor, G. W. and Cochran, W. G. (1994). Statistical methods. $8^{\text {th }}$ edn, Iowa State University Press, Ames, Iowa, USA-50010.

15. Misra, A. K., Chauhan, V., Yadav, S. K. and Maruthi Sankar, G. R. (2009). Nutritive value of commonly used feed resources in Telangana region of Andhra Pradesh. Indian J. Anim. Nutr. 26(1): 23-28.

16. Bogoro, S., Kalla D. J. U. and Gaiya. O. (2006). Effect of positioning of feed samples in two segments of the rumen on in-situ degradability of feed Stuffs. Pak. J. Nut. 5 (2): 152155.

17. Chander Datt., Reddy, G.V.N. and Kundu, S.S. (2011). Effect of feeding differently processed paddy straw based complete diets on feed intake and nutrient utilization in Nellore rams. Indian J. Anim. Nutr. 28(2): 160-165.

18. Khan, S, R., Singh, S. K. and Mudgal Vishal. (2010) Effect of feeding complete rations on the performance of lactating cross breed cows. . Indian J. Anim. Nutr. 27 (3): 261-264.

19. Islam, M., Dahlan, I. and Rajion, M. A. (2000). Effects of Ensiling and Pelleting on Nutrient Utilization of Oil Palm (Elaeis guineensis) Frond by Goats Asian-Aust. J. Anim. Sci. 13: $133-136$

20. Reddy, G. V. N., Reddy, K. J. and Nagalakshmi, D. (2002). Effect of expander-extruder processed complete diet containing Sugar cane crushed residue on growth and nutrient utilization in Ongole bull calves. Indian J. Anim. Sci. 72: 406-409.

21. ICAR. (1998). Nutrient Requirements of Livestock and Poultry, ICAR, New Delhi.

22. Beaucheminutes, K. A., Yang, W. Z. and Rode, L. M. (2003). Effects of particle size of alfalfa-based dairy cow diets on chewing activity, ruminutesal fermentation, and milk production. J. Dairy Sci. 86: 630-643.

23. Greter, A. M., DeVries, T. J. and A. G. Keyserlingk. (2008). Nutrient Intake and Feeding Behavior of Growing Dairy Heifers: Effects of Dietary Dilution. J. Dairy Sci. 91:27862795.

24. Leonardi, C. and Armentano, L. E. (2003). Effect of quantity, quality, and length of alfalfa hay on selective consumption by dairy cows. J. Dairy Sci. 86: 557-564.

25. Van Soest, P. J and J. B. Robertson. (1994). Systems of analysis for evaluating fibrous feeds. Standardization of AnalyticalMethodology in Feeds. International Research Development Center, Ottowa, Canada. 